\title{
THE FOURTH AMENDMENT: HISTORY, PURPOSE, AND REMEDIES
}

\author{
Arnold H. Loewy ${ }^{\dagger}$
}

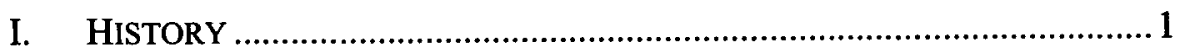

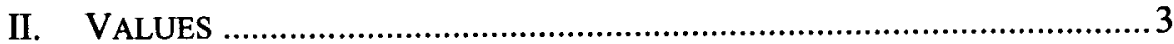

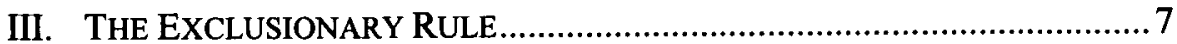

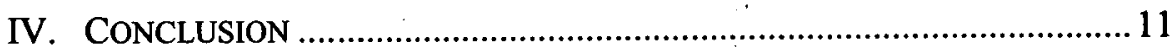

In this symposium issue, the papers are addressed primarily to three topics: (1) How important is (should) history (be) to the resolution of Fourth Amendment questions, and how good (or bad) a job does the Supreme Court do in construing history?; (2) What value(s) is (are) the Fourth Amendment intended to serve?; and (3) Is the exclusionary rule a good (the best) way of enforcing these values?

As the convenor of this symposium and the purveyor of this opening address, I deem it my function to comment briefly on each of these questions. So, I will now do so.

\section{HISTORY}

It seems to me that ordinarily if history clearly resolves a question, we should go with it. We do, of course, need to be sure that it is history that the framers liked. ${ }^{1}$ After all, part of the reason for the Fourth Amendment is that the British were conducting many searches and seizures that the colonists did not like and wished to forbid forever. ${ }^{2}$ The only other exception I can see would be that extremely rare case where history would lead to an unreasonable result and thus contravene the Reasonable Clause of the Fourth Amendment. ${ }^{3}$ Frankly, I would rate the Supreme Court's use of history as spotty and inconsistent. Let us compare, for example, Watson v. United States and Tennessee v. Garner. ${ }^{4}$

$\dagger$ George R. Killam, Jr. Professor of Criminal Law, Texas Tech University School of Law.

1. E.g., NELSON B. LASSON, THE HISTORY AND DEVELOPMENT OF THE FOURTH AMENDMENT TO THE UnITED STATES CONSTITUTION 79-83 (Leonard W. Levy, De Capo Press reprt. ed. 1970) (1937).

2. E.g., id. at 55-56.

3. Plausibly, Atwater v. City of Lago Vista is such a case. See Atwater v. City of Lago Vista, 532 U.S. 318 (2001). There the Court largely relied on history to reach an unreasonable result. See id. at 343 . Its ultimate rationale, however, was the Court's perceived need for a bright-line rule. See infra text accompanying notes $24-32$.

4. Compare Watson v. United States, 423 U.S. 411, 418 (1976) (accepting "the ancient common-law rule that a peace officer was permitted to arrest without a warrant for a misdemeanor or felony committed in 
In Watson, the Court examined the history of the right to arrest without a warrant for a felony that the police officer had probable cause to believe was committed by the arrestee. ${ }^{5}$ The Court concluded correctly that at common law, arrests for a previously committed felony without a warrant were permitted. ${ }^{6}$ Substantially, but not exclusively, because of this history, the Court upheld the right to make a warrantless arrest for a previously committed felony. ${ }^{7}$

So far so good, but there is one major question that the Court did not ask, despite the urging of Justice Marshall's dissent: whether the concept of felony meant the same today as it did at common law when the "no need for a warrant" rule developed. ${ }^{8}$ The answer seems to be pretty clearly no. At common law, all felonies were both violent and capital. ${ }^{9}$ Consequently, when a police officer saw a felon at large, it was likely a violent individual, who, if he escaped, would escape the hangman. ${ }^{10}$

Watson, on the other hand, was a non-violent credit card defrauder, who in modern times is a felon. ${ }^{11}$ Well, does history demand that this type of felon be treated the same way as the violent felons for which the common law did not require a warrant? My answer would be either "no," or at least "not necessarily." Surely the common law rule calling for the arrest of violent, capital felons tells us little about whether the same rule applies to non-violent defrauders, such as Watson. Yet, for the Supreme Court, history largely resolved the question.

In some respects, Garner presented virtually the same question, yet the Court answered it differently. Garner involved the right to use deadly force to effectuate the arrest of a fleeing burglar, who would otherwise likely escape. ${ }^{12}$ Unsurprisingly, the same common law rule that permitted warrantless arrests for all felons also permitted the use of deadly force to prevent felons from escaping arrest. So why did the Court reach a different result?

Surely, it wasn't predicated on a change in Court membership. Indeed, Justice White wrote both opinions. ${ }^{13}$ Nor was it predicated on the severity of the crime. The residential burglary involved in Garner was surely closer to a common law felony than the credit card fraud in Watson. Yet in Garner, the

\footnotetext{
his presence"), with Tennessee v. Garner, 471 U.S. 1, 11 (1985) (rejecting the common law rule that deadly force may be used against a fleeing felon who does not pose an immediate threat to officers or the public).

5. Watson, 423 U.S. at 417-19.

6. See id. at 418-19.

7. See id. The Court also considered the long-term Congressional authorization for a warrantless arrest for felonies as a reason to uphold the current statute. See id. at 423-24. Ironically, not even necessary on the facts of the case because, as Justice Marshall points out in his dissenting opinion, Watson had committed a separate felony in the officer's presence for which he unquestionably did not need a warrant. See id. at 43435 (Marshall, J., dissenting).

8. See id. at $439-42$.

9. See Tennessee v. Garner, 471 U.S. 1, 13-14 (1985).

10. See id.

11. See Watson, 423 U.S. at 426.

12. See Garner, 471 U.S. at 3.

13. See id. at 3; Watson, 423 U.S. at 412.
} 
Court carefully evaluated the differences between common law felonies and modern day felonies and concluded that the differences warranted departing from history. ${ }^{14}$

I am inclined to prefer the Garner approach although, frankly, one could argue that the Court went too far in not treating residential burglary as the type of serious felony calling for immediate capture or deadly force. ${ }^{15}$ Comparing the cases is interesting. In one sense, all Mr. Watson was asking of the government was to go through proper procedures before arresting him, whereas Mr. Garner was effectively saying: "If you can't catch me, you can't bring me to trial at all unless you're lucky enough to find me, which you probably won't be."

So, if Watson's claim was more powerful than Garner's, why did the Court defer to history in Watson, thereby allowing the seizure, and then distinguish history in Garner, thereby disallowing the seizure? I suppose the answer is that the Court was more concerned about unnecessary loss of life (Garner) than the unnecessary loss of process (Watson). But whatever might be said about the wisdom of the two cases, it seems clear that taken together, they illustrate the proposition that the Court tends to use history as a makeweight for a result that it desires on other grounds. To the extent that this is accurate, I do not think it is a good thing, nor can I give the Court high marks for its performance.

\section{VALUES}

Conventional wisdom suggests that the ultimate value sought to be preserved by the Fourth Amendment is "reasonable expectation of privacy."16 I am not sure that this is fully accurate for a number of reasons. First, I do not think that privacy, at least in the dictionary sense of the term, fully expresses the interests sought to be protected by the Fourth Amendment. For example, Justice Black was surely correct when he suggested that:

The average man would very likely not have his feelings soothed any more by having his property seized openly than by having it seized privately and by stealth. He simply wants his property left alone. And a person can be just as much, if not more, irritated, annoyed and injured by an unceremonious public arrest by a policeman as he is by a seizure in the privacy of his office or home. ${ }^{17}$

Even wording the ultimate value more correctly as "reasonable expectation of personal autonomy," I do not believe is very helpful. Rather, as I have said

14. See Garner, 471 U.S. at 13-15.

15. See id. at 27 (O'Connor, J., dissenting).

16. See Katz v. United States, 389 U.S. 347, 360 (1967) (Harlan, J., concurring).

17. Griswold v. Connecticut, 381 U.S. 479, 509 (1965) (Black, J., dissenting). 
elsewhere, the ultimate question that the Court has to answer is balancing the need to search and seize against the likelihood that the victim of the search or seizure will be innocent. ${ }^{18}$ By employing this criterion, one can put more substance on the concept of reasonableness.

There is little doubt that the Court thinks that this is what it is doing. In Florida $v$. Bostick for example, a case involving an arguably unreasonable seizure, the Court said: "We . . . reject . . . Bostick's argument that he must have been seized because no reasonable person would freely consent to a search of luggage that he or she knows contains drugs. This argument cannot prevail because the 'reasonable person' test presupposes an innocent person."19

While I think that statement in the abstract accurately reflects what the court should be doing, I have two problems with it: (1) The Court does not always follow that admonition, and (2) in the context in which the Court made the statement, it actually proved the opposite point.

In regard to the first point, consider United States v. Montoya de Hernandez, where the Court, in allowing a nearly 24-hour detention of an international traveler based on reasonable suspicion in the hope that her natural bodily functions would reveal whether or not she was an alimentary canal cocaine smuggler, reasoned thusly: "Respondent's detention was long, uncomfortable, indeed, humiliating; but both its length and its discomfort resulted solely from the method by which she chose to smuggle illicit drugs into this country."20

A moment's reflection shows that when then Justice Rehnquist wrote those words, he was not measuring the police behavior from the perspective of a hypothetically innocent person. If he had, he would have asked the question whether an innocent person who was wrongly, but reasonably, suspected of alimentary canal smuggling should be subject to this type of indignity, i.e., a person who was too frightened to defecate on command or even within a reasonable time. ${ }^{21}$ Failure to analyze the question from that perspective betrayed true Fourth Amendment values.

Indeed, Bostick itself did not seriously measure from the perspective of the innocent. The correct question should have been: "If Bostick, himself, who was carrying drugs did not feel sufficiently free to say 'no,' how likely is it that an innocent person in his situation would have felt free to say "no"'? That seems to be one of those rare questions that answers itself.

Another problem is defining what we mean by "innocent." For example, in Atwater v. City of Lago Vista, the plaintiff was undoubtedly guilty of violating a seat belt law; hence, one could contend that arresting her had

18. See Arnold H. Loewy, The Fourth Amendment as a Device for Protecting the Innocent, 81 MiCH. L. REV. 1229, 1258 (1983).

19. Florida v. Bostick, 501 U.S. 429, 437-38 (1991).

20. United States v. Montoya de Hernandez, 473 U.S. 531,544 (1985).

21. See id. at 560 n.30 (Brennan, J., dissenting). 
nothing to do with subjecting the innocent to inappropriate indignities. ${ }^{22} \mathrm{On}$ the other hand, Atwater was a frightening case to most people because although Gail Atwater was guilty, she was no more guilty than any of us who at one time or another may have inadvertently, or even intentionally, violated a minor traffic regulation. Yet few not steeped in the intricacies of Supreme Court Fourth Amendment jurisprudence would have thought it reasonable that we be hauled off to jail, handcuffed, and fingerprinted for our transgressions. ${ }^{23}$

The operative word in the preceding sentence, and indeed in the Fourth Amendment itself, is "reasonable." Indeed, in case after case, the Court has emphasized that the overarching principle of the Fourth Amendment is reasonableness. ${ }^{24}$ Most of the time when the Court cites "reasonableness" as the overarching principle, it does so to uphold a search; for example, there is no need for a warrant here because the search comports with the overarching principle of reasonableness. ${ }^{25}$ Without regard to the correctness of those decisions, one would have thought that the same principle (if indeed it is a principle) would have applied in Atwater, but it did not. The Court conceded that as applied to Atwater herself, the arrest was clearly unreasonable. ${ }^{26}$ As the Court so starkly put it: "Atwater's claim to live free of pointless indignity and confinement clearly outweighs anything the City can raise against it specific to her case. ${ }^{27}$

So, one might have thought that the finding of individual unreasonableness would have ended the case, but it did not. Rather, the Court continued: "But we have traditionally recognized that a responsible Fourth Amendment balance is not well served by standards requiring sensitive, caseby-case determinations of government need, lest every discretionary judgment in the field be converted into an occasion for constitutional review.,28

Yet just five years earlier, in Ohio v. Robinette, the Court had said: "We have long held that the 'touchstone of the Fourth Amendment is reasonableness.' Reasonableness, in turn, is measured in objective terms by examining the totality of the circumstances. In applying this test we have consistently eschewed bright-line rules, instead emphasizing the fact-specific nature of the reasonableness inquiry." 29

I suppose that a cynic could say that it all depends on whose ox is gored. If the police win with a bright-line rule (as in Atwater), then bright-line rules

22. See Atwater v. City of Lago Vista, 532 U.S. 318, 323-24 (2001).

23. See id.

24. See, e.g., United States v. Villamonte-Marquez, 462 U.S. 579, 588 (1983).

25. See United States v. Rabinowitz, 339 U.S. 56, 65 (1950); see also Brigham City, Utah v. Stuart, 547 U.S. 398, 403 (2006) ('[B] ecause the ultimate touchstone of the Fourth Amendment is 'reasonableness,' the warrant requirement is subject to certain exceptions.").

26. See Atwater, 532 U.S. at 346.

27. Id. at 347.

28. Id.

29. Ohio v. Robinette, 519 U.S. 33, 39 (1996) (quoting Florida v. Jimeno, 500 U.S. 248, 250-51 (1991)). 
are good. But if a citizen wins by employing a bright-line rule (as in Robinette), that is bad. I am inclined to favor flexibility (so that Atwater would have won, and frankly so would Robinette, if flexibility had been applied properly). But, however one might resolve that question, we can surely expect more consistency (and more reasonableness) from the Court than we saw in Atwater.

Finally, we should note that the Court sometimes applies more protection than an innocent person needs. For example, in Kyllo $v$. United States, the Court required both a warrant and probable cause to use a thermal imager to measure heat escaping from a house. ${ }^{30}$ Frankly, I do not know too many innocent people who really care if the police know how much heat they are using. I certainly do not criticize Kyllo for taking privacy, secrecy, and autonomy in the home seriously. Indeed, homes are the last bastion of security and surely where the right of an individual is at its zenith vis-à-vis the right of the states. ${ }^{31}$ But abstract theory does not decide concrete cases.

For starters, Kyllo was inconsistent with prior cases that permitted the searching for considerably more intimate details of a home, particularly Smith $v$. Maryland, which allowed the police to record every telephone number dialed from a home without probable cause, a warrant, or even reasonable suspicion. ${ }^{32}$ It is not that I am opposed to the Court correcting a mistake and imposing limitations on police where necessary to protect an innocent citizen's reasonable expectation of privacy. But, Kyllo does not do that.

What Kyllo does do is impose a standard that is so difficult for a policeman to meet relative to the benefit he can expect to obtain from conducting a thermal image that thermal imaging would almost never be used. Instead, the police are likely to make more intrusive searches. Let me illustrate. In $K y l l o$, the police had information that Kyllo was growing marijuana in his triplex unit. ${ }^{33}$ After ascertaining that he had an unusually high utility bill, the police attempted to ascertain whether that bill was caused by excessive heat (necessary to grow marijuana) emanating from Kyllo's home. ${ }^{34}$ To ascertain this, the police used a thermal imager on both Kyllo's triplex unit and that of his neighbors. ${ }^{35}$ After ascertaining that Kyllo's unit released considerably more heat than his neighbors, the police obtained a warrant, searched Kyllo's home, and found the growing marijuana. ${ }^{36}$

30. Kyllo v. United States, 533 U.S. 27, 40 (2001).

31. See Payton v. New York, 445 U.S. 573, 582 (1987); see also Griffin v. Wisconsin, 483 U.S. 868 , 883 (1980) (Blackmun, J., dissenting) (describing the home as "the place that traditionally has been regarded as the center of a person's private life, the bastion in which one has a legitimate expectation of privacy protected by the Fourth Amendment.").

32. Smith v. Maryland, 442 U.S. 735, 745-46 (1979). There was in fact probable cause in Smith, and the police could have obtained a warrant but did not. Id. at 737 . The case, however, was predicated on the assumption that obtaining all of the dialed numbers from a residence is not a search at all. See id. at 745-46.

33. Kyllo, 533 U.S. at 30.

34. Id. at 29-30.

35. Id.

36. Id. at 30 . 
In a post-Kyllo world, what's a policeman to do in a similar situation? Well, if the information and utility records are sufficient for probable cause he can get a warrant. But, why bother getting a warrant to thermal image when the same probable cause would give him a warrant to search the house? Furthermore, even if he wanted to thermal image the house, it would be useless because he wouldn't have other houses to compare them with. So you might ask, why couldn't he thermal image the other houses to get a comparison as was done in Kyllo? The answer is that if thermal imaging constitutes a search requiring probable cause, there is no way that he could thermal image a house which he doesn't even suspect of criminality. ${ }^{37}$

Thus, Kyllo virtually guarantees that the police will engage in more intrusive behavior from the perspective of the innocent, rather than the less intrusive behavior engaged in Kyllo. Of course, it is worth noting that if Kyllo had been innocent and the thermal imager showed no excessive heat emanating from the house, the innocent Kyllo never would have suffered the indignity of a search. Today, unfortunately, an innocent person in Kyllo's position probably would be searched because it would be so hard to do an effective thermal image. So, on balance, while the Court sometimes speaks of the importance of protecting the innocent, its deeds do not always match its words.

\section{THE EXCLUSIONARY RULE}

In Mapp v. Ohio, the Supreme Court answered the title question for our third panel (Is the exclusionary rule a good [the best] way to enforce Fourth Amendment values?) with a resounding "yes."38 Since then, it has expressed considerable regret with its handiwork. Starting in 1974 with United States $v$. Calandra, the Court has rather consistently bewailed the cost of the exclusionary rule, frequently suggesting that its cost is not worth its minimal benefit. $^{39}$

Calandra departed from Mapp in that Mapp held the exclusionary rule was an inherent right of the victim of the unconstitutional search. ${ }^{40}$ Calandra, on the other hand, held that whether evidence is to be excluded depends on a cost-benefit analysis, with particular emphasis on deterrence, and is no part of the Fourth Amendment itself. ${ }^{41}$ I actually prefer the Calandra approach but the Mapp result.

Let me explain. First, I agree with Calandra that the exclusionary rule is not an inherent part of the Fourth Amendment. I base that conclusion on the

37. See id. at 40 (noting that the use of thermal vision imagery requires a warrant supported by probable cause and that such imagery could invade the privacy and intimacy of the home).

38. See Mapp v. Ohio, 367 U.S. 643, 657 (1961).

39. See United States v. Calandra, 414 U.S. 338, 349 (1974).

40. Mapp, 367 U.S. at 657.

41. Calandra, 414 U.S. at 350 . 
Fourth Amendment's, unlike the Fifth or Sixth, being a substantive right. ${ }^{42}$ Consequently, the exclusionary rule can only be justified if, on a cost-benefit basis, it is worth the cost. Nevertheless, I think that the Court has erred mightily in its enforcement of the exclusionary rule for two reasons. First, it has grossly overstated the cost of the Fourth Amendment, and second, it has grossly understated the value of meaningfully enforcing the Fourth Amendment. The Court's two most recent decisions, Herring v. United States and Hudson v. Michigan, illustrate these errors very well. ${ }^{43}$

Let's begin with Herring, the Court's most recent exclusionary rule decision. A police clerk, governed by the Fourth Amendment, negligently (i.e., unreasonably) failed to remove an active arrest warrant for Bennie Dean Herring from the computer database. ${ }^{44}$ As a result, Herring was arrested, searched incident thereto, and found to be in possession of methamphetamine and a pistol (which, as a felon, he could not lawfully possess). ${ }^{45} \mathrm{He}$ was convicted of these offenses. ${ }^{46}$ Chief Justice Roberts, for the Court, upheld his conviction by expanding the good faith exception to the exclusionary rule to include certain negligent (which this surely was), but not flagrant, violations of the Fourth Amendment from the exclusionary rule. ${ }^{47}$ While conceding that negligent violations can be deterred by the exclusionary rule, the Court thought that the benefits were not worth the cost. ${ }^{48}$

Well, what were the costs? According to the Court, "The principal cost of applying the exclusionary rule is, of course, letting guilty and dangerous defendants go free-something that 'offends basic concepts of the criminal justice system.' '[T]he rule's costly toll upon truth-seeking and law enforcement objectives present a high obstacle for those urging [its] application." "49 Unsurprisingly, the Court concluded its opinion by quoting Benjamin Cardozo's famous bon mot: "In such a case [referring to one like Herring], the criminal should not 'go free because the constable has blundered." $" 50$

But, would Bennie Dean Herring have gone free because of the constable's blunder? Quite the contrary; it was only because of the constable's blunder that he was found with the methamphetamine and pistol in the first

42. See Arnold H. Loewy, Police-Obtained Evidence and the Constitution: Distinguishing Unconstitutionally Obtained Evidence from Unconstitutionally Used Evidence, 87 MICH. L. REV. 907,910
(1989).

43. See Herring v. United States, 129 S. Ct. 695, 703-04 (2009); Hudson v. Michigan, 547 U.S. 586 , 601-02 (2006).

44. Herring, 129 S. Ct. at 698.

45. Id.

46. Id. at 699 .

47. Id. at 704 .

48. Id. at 697 n.4.

49. Id. at 701 (quoting Leon v. United States, 468 U.S. 897, 908 (1984) and Pa. Bd. of Prob. \& Parole v. Scoth, 524 U.S. 357, 364-65 (1998), respectively).

50. Id. at 704 (quoting People v. Defore, 150 N.E. 585, 587 (1926) (opinion of the Court by Cardozo, J.). 
place. If the police clerk had done what she should have done and removed the no longer valid arrest warrant, Herring never would have been arrested. Thus, there would have been no evidence to exclude. So, the only cost of applying the exclusionary rule would have been to return to the status quo ante, that is, put the Government in the position in which it would have been if the government officials had done what the Fourth Amendment (and presumably us) wanted them to do, namely not arrest Herring. ${ }^{51}$

Besides overstating the cost of the exclusionary rule, much of the Court's jurisprudence understates its benefit. Specifically, I assume that for whatever value(s) we think the Fourth Amendment offers, we want them enforced. That is, we really do want the police to adhere to the strictures of the Fourth Amendment (if we don't, then my forthcoming argument will be singularly unpersuasive).

But, on the assumption that we do, Hudson v. Michigan is a case we should view with alarm. In many ways, Hudson (like United States v. Leon before it) was a contrived case in that there really was not a constitutional violation, but the Government and the Court pretended that there was in order to limit the applicability of the exclusionary rule. ${ }^{52}$ Specifically in Hudson, the police obtained a warrant to search the home of Booker Hudson, believed to be a dangerous drug dealer, for drugs and guns. ${ }^{53}$ The police knocked on his door, waited three to five seconds, turned the knob of his unlocked door, and proceeded to execute the warrant. ${ }^{54}$ As Justice Breyer so cogently demonstrated in dissent, the governmental concession that this violated Hudson's right to be free from a no-knock entry was neither necessary nor correct. ${ }^{55}$ Rather, the fact that the police reasonably suspected that Hudson was armed and dangerous was, as a matter of substantive Fourth Amendment law, sufficient to render knocking unnecessary.

So, the problem in Hudson was not upholding Hudson's conviction, but rather how the Court upheld it (by modifying the exclusionary rule) and, even more importantly, why the Court chose to modify the rule. Justice Scalia, for the Court, seems concerned that the exclusionary rule might cause police to take the knock-and-announce rule too seriously. That is, he fears that applying the exclusionary rule to knock-and-announce violations might cause the police to knock when they need not, thus risking their lives or evidence. ${ }^{56}$ Of course, the substantive rule already takes care of that fear by allowing the police to dispense with a knock if they have even reasonable suspicion that the suspect is

51. See id. at 698. Of course he would not be entitled to get his drugs and gun returned so the government would still benefit some from his misbehavior, just not as much as Herring allowed. $C f$. id. at 699 (noting that Herring did not challenge the legality of possessing the guns and drugs).

52. See id. at 615 (Breyer, J., dissenting); United States v. Leon, 468 U.S. 897, 926 (1984).

53. Hudson, 547 U.S. at 588.

54. Id. at 588 .

55. Id. at 616, 623-24 (Breyer, J., dissenting).

56. Id. at 596 . (majority opinion). 
armed and dangerous or that the evidence may be destroyed. ${ }^{57}$ If the Court thinks that is not enough flexibility, however, it could simply abolish the rule. Instead, the Court effectively says, "No, we'll keep the rule; we'll just eliminate any serious incentive to follow it." Surely this is not a high point in Supreme Court jurisprudence.

Perhaps even more disturbing is Justice Scalia's blithe assertion that "deterrence of knock-and-announce violations is not worth a lot." ${ }^{.58}$ And why does he think that? His answer is: "[I]gnoring knock-and-announce can realistically be expected to achieve absolutely nothing except the prevention of destruction of evidence and the avoidance of life-threatening resistance by occupants of the premises ....",59

The falsity of this statement is apparent as soon as one remembers that the primary point of the Fourth Amendment is to protect the innocent. ${ }^{60}$ So, the person that we really care about in the no-knock situation is the person who may, in fact, be completely innocent, but nevertheless, completely frightened by an unannounced entry into her home. One can easily imagine a frail woman with a weak heart who is reasonably but mistakenly believed to either be or to house a criminal or evidence of crime. The knock-and-announce rule is designed to protect her, not the Booker Hudsons of the world. Indeed, if the shock of the no-knock entry were to cause our hypothetical woman to die of a heart attack, I would like to see Justice Scalia explain to her grieving widower how deterring knock-and-announce violations can "be expected to achieve absolutely nothing."

The point here, of course, is that if the Fourth Amendment rule is worth having, then it is worth enforcing. It is a sorry excuse for not applying the exclusionary rule that we want to keep the underlying Fourth Amendment rule; we just don't want the police to take it too seriously.

One final point I'd like to make in regard to the exclusionary rule is that I believe the Court went down the wrong road in adopting the standing doctrine. If the exclusionary rule were predicated on the Mapp theory - that it is part and parcel of the individual's Fourth Amendment right-standing would make perfect sense. ${ }^{62}$ But the Court did not go down that road. ${ }^{63}$ Rather, it held (correctly, in my view) that the exclusionary rule should depend on a costbenefit deterrent analysis. ${ }^{64}$ Telling the police that if they willfully violate

57. Id.

58. Id. at 596 .

59. Id.

60. See generally Loewy, The Fourth Amendment as a Device for Protecting the Innocent, supra note 18, at 1272 (emphasizing that the primary purpose of the Reasonable Clause of the Fourth Amendment is to protect the innocent).

61. Hudson, 547 U.S. at 596.

62. See Mapp v. Ohio, 367 U.S. 643, 650-51 (1961).

63. Hudson, 547 U.S. at 591.

64. See United States v. Calandra, 414 U.S. 338, 349-54 (1974). 
person A's Fourth Amendment rights, then they can use the evidence against person B surely creates an incentive to do just that.

The paradigm case is Payner v. United States, in which the IRS deliberately violated the Fourth Amendment rights of a Bahamian banker visiting the United States, knowing that they would not use the evidence against him but only against his clients. The plan worked perfectly. The IRS flagrantly violated the banker's rights. ${ }^{65}$ It did obtain evidence against one of his clients that it used to obtain a conviction. ${ }^{66}$ Seemingly ignoring the regulatory purpose of the exclusionary rule, the Court had no difficulty upholding the conviction of the banker's client. ${ }^{67}$ Surely, the exclusionary rule applied in such a manner cannot bring about the desired deterrence. ${ }^{68}$ Again, this assumes that we really do desire to deter Fourth Amendment violations. I should think that we do, but frankly, I am not so sure that the Court is on board.

\section{CONCLUSION}

I suppose that I've been less than laudatory towards the Supreme Court's use of history, articulation of values, and appropriate use of the exclusionary rule. Perhaps others will give the Court higher marks. I look forward to hearing the discussion from our panels for the remainder of the day and the articles that result from this year's Symposium.

65. Payner v. United States, 447 U.S. 727, 730 (1980).

66. Id. at 729-30.

67. See id. at 736-37.

68. See id. at 746-47 (Marshall, J., dissenting). 
